\title{
Characterization of Bacillus stearothermophilus Plasmid pAB124 and Construction of Deletion Variants
}

\author{
By ALISTAIR H. A. BINGHAM,* CHRIS J. BRUTON $\dagger$ \\ AND TONY ATKINSON \\ Public Health Laboratory Service, Centre for Applied Microbiology and Research, \\ Porton, Salisbury, Wiltshire SP4 OJG
}

(Received 18 October 1979; revised 26 January 1980)

\begin{abstract}
A restriction endonuclease cleavage map of the tetracycline resistance plasmid pAB124, originally isolated from Bacillus stearothermophilus, was constructed using ten enzymes. Tetracycline resistance was associated with a 1.95 megadalton (Md) region of pAB124 lying between two EcoRI sites, and this region was circularized to produce a viable tetracycline resistance plasmid (pAB224), with two EcoRI fragments of pAB124 deleted amounting to $0.95 \mathrm{Md}$. A second plasmid (pAB524) with one EcoRI fragment (0.6 Md) of pAB124 deleted was also constructed. Restriction endonuclease cleavage maps of pAB224 and pAB524 were constructed.
\end{abstract}

\section{INTRODUCTION}

Several plasmids have been isolated from Gram-positive spore-forming bacilli, e.g. Bacillus pumilus (Lovett \& Bramucci, 1975), B. megaterium (Carlton \& Helinski, 1969) and B. subtilis (Tanaka et al., 1977; Le Hegarat \& Anagnostopoulos, 1977), although none of these has been shown to be associated with any phenotypic trait. More recently, a plasmid from $B$. cereus coding for tetracycline resistance and one from $B$. subtilis producing a bacteriocin have been isolated (Bernhard et al., 1978).

The presence of a plasmid in a bacteriocin (thermocin)-producing strain of B. stearothermophilus has recently been reported (Sharp et al., 1979), and we have described the isolation of four plasmids from antibiotic-resistant thermophilic bacilli (Bingham et al., 1979), one of which (pAB124) was shown to confer tetracycline resistance on B. subtilis. This paper describes the characterization of pAB124 and the construction of deletion variants of this plasmid.

\section{METHODS}

Bacterial strains. Thermophilic Bacillus strain TB124, isolated as previously described (Bingham et al., 1979), was classified as Bacillus stearothermophilus using standard identification procedures (Cowan \& Steel, 1974). Bacillus subtilis harbouring plasmid pAB124 was prepared by direct plasmid transformation. Bacillus subtilis IG20 (hsr hsm trp) was kindly provided by A. Docherty, Department of Bacteriology, Bristol University.

Culture media. For plasmid isolation all strains were grown on TYS medium (Bingham et al., 1979) supplemented with tetracycline at $25 \mu \mathrm{g} \mathrm{ml}^{-1}$. The following minimal medium (SMS) was used for $B$, subtilis $\left(\mathrm{g} \mathrm{l}^{-1}\right):\left(\mathrm{NH}_{4}\right)_{2} \mathrm{SO}_{4}, 2 ; \mathrm{K}_{2} \mathrm{HPO}_{4}, 14 ; \mathrm{KH}_{2} \mathrm{PO}_{4}, 6$; sodium citrate, $1 ; \mathrm{MgSO}_{4} .7 \mathrm{H}_{2} \mathrm{O}, 0 \cdot 2 ;$ glucose, 5.

Isolation of plasmid DNA. This was carried out with $400 \mathrm{ml}$ cultures using the procedure previously described (Bingham et al., 1979). Plasmid pAB124 was originally isolated from $B$. stearothermophilus TB124 and transformed into $B$. subtilis (Bingham et al., 1979). All experiments described in this paper used pAB124 isolated from $B$. subtilis. Plasmid pUB1654 was a gift from A. Docherty.

$\dagger$ Present address: Department of Biochemistry, Imperial College, South Kensington, London SW7 2AZ. 
Small-scale plasmid preparation. This was used for extracting recombinant DNA from large numbers of clones. Cultures $(15 \mathrm{ml})$ in TYS medium containing the selective antibiotic(s) were grown overnight at $37^{\circ} \mathrm{C}$ without shaking. Cells were harvested at $10000 \mathrm{~g}$, washed once in $5 \mathrm{ml} \mathrm{TES}$ buffer $(30 \mathrm{~mm}$-Tris/ $\mathrm{HCl} \mathrm{pH} 8 \cdot 0$, $5 \mathrm{~mm}-\mathrm{Na}_{2}$ EDTA, $\left.50 \mathrm{mM}-\mathrm{NaCl}\right)$ and resuspended in $100 \mu \mathrm{l}$ TES. EDTA $(25 \mu \mathrm{l}, 0.25 \mathrm{M})$ and lysozyme $(25 \mu \mathrm{l}$, $15 \mathrm{mg} \mathrm{ml}^{-1}$ ) were added and the suspension was shaken gently on ice for $10 \mathrm{~min}$. The suspension was then placed in a $37{ }^{\circ} \mathrm{C}$ water bath for 5 min and $25 \mu$ l sodium dodecyl sulphate $(10 \%, \mathrm{w} / \mathrm{v})$ was added, to bring about lysis, followed by $50 \mu \mathrm{l} \mathrm{NaCl}(5 \mathrm{M})$; this mixture was left at $0{ }^{\circ} \mathrm{C}$ for 2.5 to $3 \mathrm{~h}$. A cleared lysate was obtained by centrifugation at $45000 \mathrm{~g}$ for $45 \mathrm{~min}$, and this was then extracted twice with chloroform/3methylbutan-1-ol $(24: 1, v / v)$, once with phenol (freshly distilled over $N_{2}$ ) equilibrated in TES buffer and three times with diethyl ether. The plasmid DNA obtained was suitable for restriction endonuclease analysis.

Plasmid transformation. Bacillus subtilis IG20 was grown overnight at $37^{\circ} \mathrm{C}$ in $200 \mathrm{ml}$ SMS medium supplemented with $0.5 \mathrm{ml}$ tryptophan $\left(2 \mathrm{mg} \mathrm{ml}^{-1}\right)$ and then diluted with an equal volume of similar medium (prewarmed). The absorbance $(540 \mathrm{~nm}$ ) was monitored at $30 \mathrm{~min}$ intervals, and at a value equivalent to maximum competence ( 30 to $60 \mathrm{~min}$ after cessation of exponential growth) $1 \mathrm{ml}$ samples of the culture were added to plasmid DNA $(0.5$ to $5 \mu \mathrm{g})$ in $50 \mu \mathrm{l}$ polyethylene glycol $1000(50 \%, \mathrm{w} / \mathrm{v})$ and incubated for $1 \mathrm{~h}$ at $37^{\circ} \mathrm{C}$ with vigorous aeration. Prewarmed TYS medium $(5 \mathrm{ml})$ was then added and incubation was continued for a further hour prior to plating on selective media. Selective concentrations of antibiotics used were $25 \mu \mathrm{g} \mathrm{ml}^{-1}$ for tetracycline and neomycin and $75 \mu \mathrm{g} \mathrm{ml}^{-1}$ for streptomycin. It was not necessary to induce competence by dilution of the culture into a starvation medium (Stacey, 1968).

Restriction endonucleases. Eco RI and CauII were purified by procedures developed in this laboratory and digestions were carried out in buffers previously described (Bingham et al., 1979). BstEII, HaeII, HhaI, HindI, HpaI, HpaII, Thal, $\mathrm{XbaI}$ and T4-DNA ligase were purchased from Uniscience Ltd, Cambridge, and digestions carried out in the buffers recommended by the manufacturer. Reaction mixtures contained 0.5 to $1 \mu \mathrm{g}$ plasmid DNA in a final volume of 20 to $25 \mu \mathrm{l}$, and reactions were terminated by adding $\mathrm{Na}_{2}$ EDTA to a final concentration of $10 \mathrm{~mm}\left(\mathrm{CauII}\right.$, Bst EII, ThaI) or heating at $66^{\circ} \mathrm{C}$ for $10 \mathrm{~min}$. For double digestions involving enzymes with different buffer requirements, plasmid DNA was first digested with the enzyme requiring the buffer of lower ionic strength, and then the buffer was adjusted with $10 \times$ concentrated components prior to the addition of the second enzyme.

Agarose gels $(0.8 \%$ w/v) were used as previously described (Bingham et al., 1979), with an EcoRI plus HindIII $\lambda$ CI857 digest providing fragments of standard sizes: 13.4, 3.35, 3.2, 2.8, 2.32, 1.39, 1.27, 1.05, 0.89, $0.59,0.47$ and 0.31 megadaltons (Md) (Murray \& Murray, 1975). The sizes of unknown fragments were determined graphically from a $10 \times$ enlargement of a photograph $(35 \mathrm{~mm})$ and were taken as an average of three estimations.

Cloning of pAB124 EcoRI fragments. Plasmids pAB124 $(1 \mu \mathrm{g})$ and pUB1654 $(1 \mu \mathrm{g})$ were digested to completion with $E c o$ RI and then the enzyme was denatured by heating at $66^{\circ} \mathrm{C}$ for $10 \mathrm{~min}$. The fragments were precipitated by adding $3 \mathrm{M}$-sodium acetate to a final concentration of $0.3 \mathrm{M}$ and $2 \mathrm{vol}$. cold $\left(-20^{\circ} \mathrm{C}\right)$ ethanol. After $10 \mathrm{~min}$ in a solid $\mathrm{CO}_{2}$ /ethanol bath the precipitate was collected by centrifugation. After removal of all the ethanol the precipitate was resuspended in T4 ligase buffer $\left(66 \mathrm{~mm}-\mathrm{Tris} / \mathrm{HCl} \mathrm{pH} 7 \cdot 6,6.6 \mathrm{~mm}-\mathrm{MgCl}_{2}\right.$, $10 \mathrm{~mm}$-dithiothreitol, 0.4 mM-ATP) and incubated overnight at $4{ }^{\circ} \mathrm{C}$ with 0.05 units T4-DNA ligase.

\section{RESULTS}

\section{Restriction endonuclease site mapping of $\mathrm{pAB} 124$}

The fragment sizes obtained by digestion of pAB124 DNA (isolated from B. subtilis) with BstEII, CauII, EcoRI, HaeIII, HindII, HhaI, HpaI, HpaII, ThaI and $X b a \mathrm{I}$ are given in Table 1. These sizes were determined graphically using a lambda DNA digested with HindIII plus EcoRI as standards subjected to electrophoresis on the same gels as the unknown fragments. The average value for the total size of pAB124 was close to $2.9 \mathrm{Md}$. A series of double digestion experiments was carried out in order to construct a cleavage map of pAB124 (Table 2).

The positions of the four single sites (BstEII, CauII, HpaI, XbaI) relative to each other were determined taking $C a u I I$ as the reference point. An Hpal plus CauII digest and a BstEII plus CauII digest both gave a small fragment of $0.35 \mathrm{Md}$; thus the BstEII and $H p a \mathrm{I}$ sites are the same distance from CauII site either on the same side, i.e. very close together, or on opposite sides $0.7 \mathrm{Md}$ apart. The latter position was confirmed by a BstEII plus $H p a I$ double digestion. The CauII plus $X b a I$ digestion generated fragments of 1.85 and $1.05 \mathrm{Md}$. It was assumed that the $X b a \mathrm{I}$ site was $1.85 \mathrm{Md}$ to the right of $C a u \mathrm{II}$ and the $H p a \mathrm{I}$ 
Table 1. Fragments produced by restriction endonuclease digestion of pAB124

Digestions and agarose-gel electrophoresis were carried out as described in Methods using plasmid DNA isolated from $B$. subtilis.

$\begin{array}{lcccc}\text { Enzyme } & \overbrace{\text { A }} \text { Bragment size (Md) } & \text { C } & \begin{array}{c}\text { Sum of fragment } \\ \text { sizes (Md) }\end{array} \\ \text { Bst EII } & 2.90 & & & 2.90 \\ \text { CauIl } & 2.90 & & & 2.90 \\ \text { HpaI } & 2.90 & & & 2.90 \\ \text { XbaI } & 2.90 & & & 2.90 \\ \text { HhaI } & 2.23 & 0.70 & & 2.93 \\ \text { HindII } & 2.30 & 0.62 & & 2.92 \\ \text { HaeIII } & 1.50 & 1.18 & 0.25 & 2.93 \\ \text { HpaII } & 1.80 & 0.70 & 0.42 & 2.92 \\ \text { ThaI } & 1.84 & 0.65 & 0.40 & 2.89 \\ \text { EcoRI } & 1.95 & 0.61 & 0.33 & 2.89\end{array}$

Table 2. Fragments produced by digestion of pAB124 with two restriction endonucleases

Double digestions and agarose-gel electrophoresis were carried out as described in Methods using plasmid DNA isolated from $B$. subtilis.

\begin{tabular}{|c|c|c|c|c|c|}
\hline \multirow[b]{2}{*}{ Enzyme pair } & \multicolumn{4}{|c|}{ Fragment size (Md) } & \multirow{2}{*}{$\begin{array}{l}\text { Sum of fragment } \\
\text { sizes (Md) }\end{array}$} \\
\hline & A & $\mathbf{B}$ & C & D & \\
\hline $\begin{array}{l}\text { Bst } \mathrm{EII}+\text { CauIl } \\
\text { Bst } \mathrm{EII}+\text { HpaI } \\
\text { Bst } \mathrm{EII}+\text { XbaI } \\
\text { CauI+HpaI } \\
\text { CauII+XbaI } \\
\text { HpaI+XbaI }\end{array}$ & $\begin{array}{l}2 \cdot 55 \\
2 \cdot 23 \\
2 \cdot 20 \\
2 \cdot 57 \\
1 \cdot 85 \\
1 \cdot 48\end{array}$ & $\begin{array}{l}0.35 \\
0.70 \\
0.70 \\
0.35 \\
1.05 \\
1.40\end{array}$ & & & $\begin{array}{l}2 \cdot 90 \\
2 \cdot 93 \\
2 \cdot 90 \\
2 \cdot 92 \\
2 \cdot 90 \\
2 \cdot 88\end{array}$ \\
\hline$H h a \mathrm{I}+\mathrm{CauII}$ & $2 \cdot 20$ & 0.44 & 0.25 & & $2 \cdot 89$ \\
\hline HhaI + XbaI & $1 \cdot 59$ & 0.71 & $0 \cdot 60$ & & $2 \cdot 90$ \\
\hline$H h a \mathrm{I}+H p a \mathrm{I}$ & $2 \cdot 10$ & 0.70 & $0 \cdot 10$ & & $2 \cdot 90$ \\
\hline HindII + CauII & $2 \cdot 30$ & $0 \cdot 33$ & $0 \cdot 28$ & & $2 \cdot 91$ \\
\hline HindII + Xbal & $1 \cdot 50$ & 0.78 & 0.62 & & $2 \cdot 90$ \\
\hline$H$ indII $+H p a \mathrm{I}$ & $2 \cdot 30$ & $0 \cdot 61$ & - & & $2 \cdot 91$ \\
\hline HaeIII + CauII & $1 \cdot 24$ & $1 \cdot 18$ & $0 \cdot 25$ & $0 \cdot 24$ & $2 \cdot 91$ \\
\hline HaeIII+Bst EII & $1 \cdot 18$ & 0.89 & 0.59 & $0 \cdot 25$ & 2.91 \\
\hline$H a e \amalg+X b a I$ & $1 \cdot 30$ & $1 \cdot 18$ & $0 \cdot 25$ & $0 \cdot 18$ & $2 \cdot 91$ \\
\hline HaeIII + HpaI & $1 \cdot 51$ & $1 \cdot 19$ & $0 \cdot 16$ & $0 \cdot 10$ & 2.96 \\
\hline HpaII+CauII & 1.80 & 0.70 & $0 \cdot 42$ & - & $2 \cdot 92$ \\
\hline$H p a \mathrm{II}+B s t \mathrm{EII}$ & $1 \cdot 80$ & 0.42 & $0 \cdot 35$ & $0 \cdot 32$ & $2 \cdot 89$ \\
\hline$H p a \mathrm{II}+X b a \mathrm{I}$ & $1 \cdot 80$ & 0.70 & $0 \cdot 38$ & $(0.05) \dagger$ & $2 \cdot 93$ \\
\hline$H p a \mathrm{II}+H p a \mathrm{I}$ & 1.45 & 0.72 & 0.42 & 0.35 & $2 \cdot 94$ \\
\hline ThaI + CauI & $1 \cdot 80$ & 0.42 & 0.40 & $0 \cdot 23$ & $2 \cdot 85$ \\
\hline ThaI + Bst EII & 1.83 & 0.62 & 0.40 & $(0.05) \dagger$ & $2 \cdot 90$ \\
\hline Thal $+X b a \mathrm{I}$ & $1 \cdot 60$ & 0.65 & $0 \cdot 40$ & 0.26 & $2 \cdot 91$ \\
\hline ThaI + HpaI & 1.75 & 0.65 & $0 \cdot 40$ & $0 \cdot 10$ & 2.90 \\
\hline EcoRI + CauII & $1 \cdot 55$ & 0.60 & $0 \cdot 40$ & 0.33 & $2 \cdot 88$ \\
\hline$E c o R I+B s t$ EII & 1.90 & 0.62 & $0 \cdot 33$ & $(0.05) \dagger$ & $2 \cdot 90$ \\
\hline$E c o R I+X b a I$ & 1.95 & $0.33^{*}$ & 0.29 & - & $2 \cdot 88$ \\
\hline$E c o \mathrm{RI}+H p a \mathrm{I}$ & $1 \cdot 20$ & 0.75 & $0 \cdot 60$ & $0 \cdot 32$ & $2 \cdot 87$ \\
\hline
\end{tabular}

and Bst EII sites were positioned using this orientation. If $\mathrm{HpaI}$ lies $0.35 \mathrm{Md}$ to the right of the CauII site a double digestion with $\mathrm{HpaI}$ plus $\mathrm{XbaI}$ would generate 1.48 and $1.40 \mathrm{Md}$ fragments, whereas if it lies $0.35 \mathrm{Md}$ to the left, 0.8 and $2.1 \mathrm{Md}$ fragments would be generated. Since fragments of the former sizes were obtained, the HpaI site must lie to the right of the 


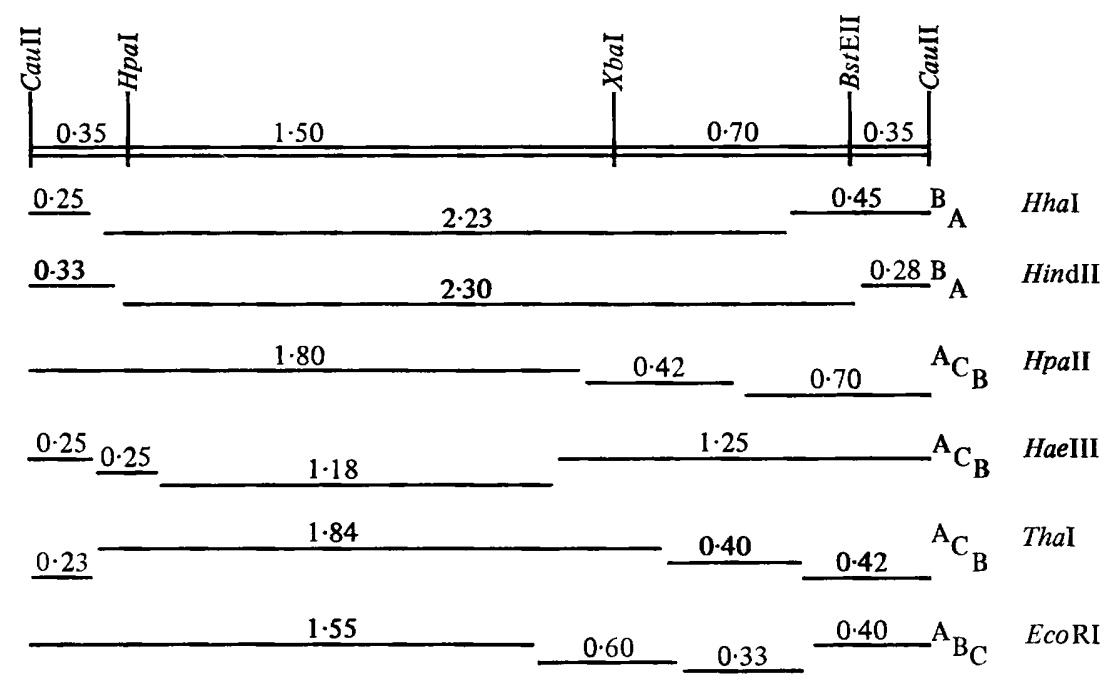

Fig. 1. Relative positions of fragments produced by digestion of pAB124 with several restriction endonucleases.

CauII site with the Bst EII site $0.35 \mathrm{Md}$ to the left. The positions of the four sites (Fig. 1) were consistent with the results of all the double digestions carried out.

Using these four single sites as reference points the fragments generated by HhaI, HindII, HpaII, HaeIII, ThaI and EcoRI (Table 1) were ordered using the established techniques of double-digestion mapping. For example, the EcoRI fragments were ordered easily as only one position of EcoRI fragment A was consistent with it containing the BstEII, CauII and $H p a \mathrm{I}$ sites but not the $\mathrm{Xba \textrm {I }}$ site which is present in $E c o$ RI fragment B. A CauII plus EcoRI digestion generated 1.55 amd 0.4 Md fragments from EcoRI A; the 1.55 Md fragment could only lie to the right of the CauII site with the $0.4 \mathrm{Md}$ fragment to the left (Fig. 1). The $E c o$ RI B fragment must lie to the right of EcoRI A over the $X b a I$ site in the position shown (Fig. 1) since an EcoRI plus $X b a \mathrm{I}$ digest yielded 0.33 and $0.29 \mathrm{Md}$ fragments from EcoRI B and the distance from EcoRI A to the $X b a \mathrm{I}$ site is $0.35 \mathrm{Md}$. The remaining fragment, $E c o$ RI C, therefore lies to the right of EcoRI B.

The fragments generated by digestion of pAB124 with HhaI, HindII, HaeIII, HpaII and ThaI were ordered in a similar manner and their relative positions are shown in Fig. 1.

Cloning of Eco $\mathrm{RI}$ fragments of $\mathrm{pAB} 124$ carrying the tetracycline resistance gene

Staphylococcal plasmid pUB1654 conferring streptomycin and neomycin resistance was used. This has a single EcoRI site lying within the streptomycin resistance gene (A. Docherty, personal communication). It would therefore be expected that insertion of pAB124 fragments at this site would inactivate streptomycin resistance. Transformation of the ligated fragments generated about $35 \%$ of clones that were $\mathrm{Nm}^{\mathrm{r}} \mathrm{Str}^{\mathrm{s}} \mathrm{Tc}^{\mathrm{r}}$. DNA was extracted from several of these clones and was analysed with EcoRI (Table 3). The minimum requirement for tetracycline resistance was shown to be the EcoRI fragment A $(1.95 \mathrm{Md})$ of pAB124 present alone in $50 \%$ of the recombinant molecules examined.

\section{Construction of small tetracycline resistance plasmids from cloned Eco RI fragments of $\mathrm{pAB} 124$}

Plasmid DNA from each type of clone, representing all combinations of pAB124 EcoRI fragments (Table 3), was digested to completion with EcoRI and then ligated with T4-DNA ligase. The DNA was then transformed into B. subtilis IG20 and $\mathrm{Tc}^{\mathrm{r}} \mathrm{Nm}^{8} \mathrm{Str}^{8}$ clones were identified. Two types of plasmid were isolated from the clones examined (Table 4): pAB224 
Table 3. Restriction endonuclease analysis of recombinant plasmids of pAB124 and pUB1654

Plasmid DNA was extracted from clones of $\mathrm{Nm}^{\mathrm{r}} \mathrm{Str}^{\mathrm{s}} \mathrm{Tc}^{\mathrm{r}}$ phenotype and digested with EcoRI as described in Methods.

\begin{tabular}{|c|c|c|c|c|}
\hline \multicolumn{2}{|c|}{ Clones identified } & \multicolumn{2}{|c|}{ EcoRI digestion } & \multirow[b]{2}{*}{$\begin{array}{l}\text { Type of } \\
\text { recombinant }\end{array}$} \\
\hline No. & $\begin{array}{l}\text { Plasmid size } \\
\text { (Md) }\end{array}$ & $\begin{array}{l}\text { Fragment size } \\
\text { (Md) }\end{array}$ & $\begin{array}{l}\text { pAB124 fragment(s) } \\
\text { inserted }\end{array}$ & \\
\hline 10 & $6 \cdot 0$ & $\begin{array}{l}4 \cdot 0^{*} \\
1 \cdot 95\end{array}$ & $\overline{\mathbf{A}}$ & I \\
\hline 3 & $6 \cdot 55$ & $\begin{array}{l}4 \cdot 0^{*} \\
1 \cdot 95 \\
0 \cdot 60\end{array}$ & $\begin{array}{l}\bar{A} \\
\mathrm{~B}\end{array}$ & II \\
\hline 2 & $6 \cdot 30$ & $\begin{array}{l}4.0^{*} \\
1.95 \\
0.32\end{array}$ & $\begin{array}{l}\bar{A} \\
\mathrm{C}\end{array}$ & III \\
\hline 4 & 6.90 & $\begin{array}{l}4 \cdot 0^{*} \\
1.95 \\
0 \cdot 60 \\
0.32\end{array}$ & $\begin{array}{l}-\bar{A} \\
\text { B } \\
\text { C }\end{array}$ & IV \\
\hline
\end{tabular}

* This fragment corresponds to pUB1654.

Table 4. EcoRI analysis of tetracycline resistance plasmids derived from pAB124:pUB1654 recombinant molecules

Plasmid DNA was extracted from $\mathrm{Tc}^{\mathrm{r}} \mathrm{Nm}^{s} \mathrm{Str}^{\mathrm{s}}$ clones and digested with EcoRI as described in Methods.

\begin{tabular}{|c|c|c|c|c|c|}
\hline \multicolumn{2}{|c|}{ DNA source* } & \multicolumn{4}{|c|}{ Tetracycline resistance plasmids } \\
\hline $\begin{array}{l}\text { Type of } \\
\text { recombinant }\end{array}$ & $\begin{array}{c}\text { pAB124 EcoRI } \\
\text { fragment(s) present }\end{array}$ & No. of clones $\dagger$ & Size $(\mathrm{Md})$ & $\begin{array}{c}\text { EcoRI fragments } \\
(\mathrm{Md})\end{array}$ & $\begin{array}{l}\text { pAB124 EcoRI } \\
\text { fragment(s) present }\end{array}$ \\
\hline I & A & 10 & 1.95 & $1 \cdot 95$ & A (pAB224) \\
\hline II & $\mathbf{A}+\mathbf{B}$ & 10 & 1.95 & 1.95 & $A(p A B 224)$ \\
\hline \multirow[t]{2}{*}{ III } & $\mathrm{A}+\mathrm{C}$ & 7 & 1.95 & 1.95 & $\mathrm{~A}(\mathrm{pAB} 224)$ \\
\hline & & 3 & $2 \cdot 3$ & $1 \cdot 95,0.32$ & $A+C(p A B 524)$ \\
\hline \multirow[t]{2}{*}{ IV } & $\mathrm{A}+\mathrm{B}+\mathrm{C}$ & 8 & 1.95 & 1.95 & $\mathrm{~A}(\mathrm{pAB} 224)$ \\
\hline & & 2 & $2 \cdot 3$ & $1 \cdot 95,0.32$ & $A+C(p A B 524)$ \\
\hline
\end{tabular}

which was the recircularized EcoRI fragment A of pAB124 (1.95 Md) and pAB524 containing EcoRI fragments A plus C $(2 \cdot 3 \mathrm{Md})$. No plasmids containing EcoRI fragments A plus $\mathrm{B}$ or reconstructed pAB124 were detected.

Plasmid pAB224 was shown to contain seven single sites (EcoRI, BstEII, CauII, HpaII, $H h a \mathrm{I}, T h a \mathrm{I}$ and $H p a \mathrm{I})$. The position of each site was determined by double digestions and was shown to be consistent with pAB224 being the recircularized EcoRI fragment A of pAB124 (Fig. 2). Therefore EcoRI A contains the tetracycline resistance genes and all the known essential functions of $\mathrm{pAB} 124$.

An EcoRI digest of pAB524 generated fragments of $1.95 \mathrm{Md}$ and $0.32 \mathrm{Md}$. The larger fragment contained BstEII, CauII and $H p a \mathrm{I}$ sites and double digestions confirmed that it was the EcoRI fragment A of pAB124; the smaller fragment contained HhaI and HpaII sites and was assumed to be the EcoRI fragment C of pAB124. Two orientations of EcoRI C within pAB524 were possible and each would give different sized fragments when digested with HpaII or HhaI. The observed sizes of the fragments obtained from five different examples of pAB524 indicated that the order of EcoRI fragments A and C was the same as that observed in pAB124 (Fig. 2). 


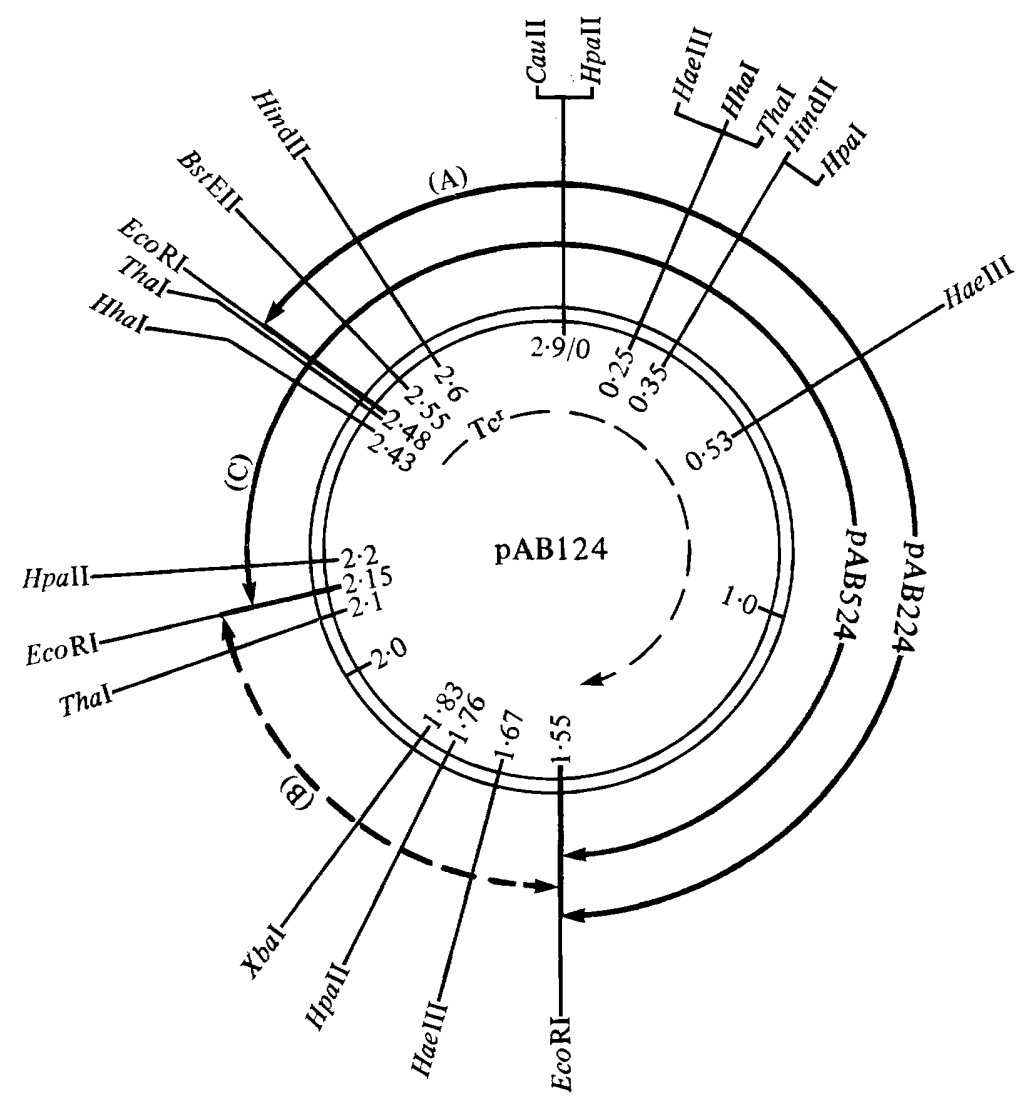

Fig. 2. Restriction endonuclease cleavage map of pAB124, pAB224 and pAB524.

\section{DISCUSSION}

Classification of the thermophilic bacilli harbouring pAB124 by standard procedures indicated that the strains were quite closely related to B. stearothermophilus but not identical to the neotype strain NCA 1503 . The aim of this research is to develop a vector for cloning in $B$. stearothermophilus and pAB124 could provide the basis for such a vector. The expression of pAB124 in $B$. subtilis will also allow the use of this plasmid as a vector for gene cloning in this organism, and it is important to note that the plasmid is stable with no apparent alteration upon uptake and replication in $B$. subtilis, as determined by restriction endonuclease analysis. The transformation frequencies, however, are lower with plasmid DNA isolated from $B$. stearothermophilus than with that from $B$. subtilis; this may in part be due to the formation of concatemers in $B$. subtilis that transform at a higher frequency than the monomeric species (Canosi et al., 1978). The most convenient restriction site for cloning in pAB124 is the single $X b a I$, since this enzyme produces a cohesive terminus and lies within the region of pAB124 not essential for tetracycline resistance or plasmid replication (Fig. 2). We have successfully inserted a staphylococcal neomycin resistance plasmid (pUB110) at the $X b a \mathrm{I}$ site without inactivating tetracycline resistance. Of the remaining single restriction sites in pAB124, it is not known whether Bst EII and Caull produce a cohesive terminus and $H p a \mathrm{I}$ is known to produce base-paired termini, thus making the use of these sites for cloning more difficult. In addition, these latter sites lie within the region of pAB124 that appears to be associated with tetracycline resistance.

The development of the staphylococcal vector pUB1654 $\left(\mathrm{Nm}^{\mathrm{r}} \mathrm{Str}^{\mathrm{r}}\right.$; A. Docherty, personal communication) allowed us to examine which region of pAB124 contained the 
tetracycline resistance genes. Only the large EcoRI fragment (A) was essential for the expression of the $\mathrm{Tc}^{\mathrm{r}}$ phenotype and the survival of the plasmid as a replicon. The circularized EcoRI fragment A (pAB224) contained one site for each of seven restriction endonucleases (Fig. 2); three of these enzymes produce a cohesive terminus (EcoRI, HpaII and $H h a \mathrm{I})$, and therefore this plasmid is of potential use as a small $(1.95 \mathrm{Md})$ vector for gene cloning. We have attempted to insert at the $E c o$ RI site the $B$. licheniformis $\beta$-lactamase that is cloned between two EcoRI sites in a lambda vector (W.J. Brammar, personal communication) and also the $\beta$-lactamase of the staphylococcal plasmid pI258 (Novick et al., 1979). In both cases we could not isolate recombinant molecules containing a $\beta$-lactamase gene. We are therefore continuing to examine the ability of pAB224 to express genes cloned at the EcoRI site.

The construction of pAB524 in a similar manner to pAB224 gives rise to a plasmid with two EcoRI, two HpaII and two HhaI sites, but no XbaI site. A potentially useful deletion plasmid would be that formed by circularization of EcoRI fragments A plus B of pAB124, which would retain the single $X b a \mathrm{I}$ site and also contain one $H h a \mathrm{I}$ site. However, repeated ligations of EcoRI-digested recombinants of pUB1654 containing EcoRI fragments A plus $\mathrm{B}$ failed to generate this plasmid; only pAB224 (EcoRI A) and pUB1654 containing EcoRI fragment $\mathrm{A}$ of pAB124 were obtained. This was rather surprising since one would expect circularization of EcoRI fragments A plus B to be about as efficient as circularization of EcoRI fragments A plus C (pAB524; Table 4).

We intend to examine the ability of pAB124 and pAB224 to express chromosomal functions cloned at the $X b a I$ and $E c o$ RI sites, respectively, in order to evaluate their use as vectors for gene cloning in Bacillus species.

We thank A. Docherty for providing pUB1654 DNA. This work was supported by a grant from the Health and Safety Executive.

\section{REFERENCES}

Bernhard, K., Schrempf, H. \& Goebel, W. (1978). Bacteriocin and antibiotic resistant plasmids in Bacillus cereus and Bacillus subtilis. Journal of Bacteriology 133, 897-903.

Bingham, A. H. A., Bruton, C. J. \& Atkinson, T. (1979). Isolation and partial characterization of four plasmids from antibiotic-resistant thermophilic bacilli. Journal of General Microbiology 114, 401-408.

Canosi, U., Morelli, G. \& Trautiner, T. A. (1978). The relationship between molecular structure and transformation efficiency of some $S$. aureus plasmids isolated from B. subtilis. Molecular and General Genetics 166, 259-267.

Carlton, B. C. \& Helinski, D. R. (1969). Heterogeneous circular DNA elements in vegetative cultures of Bacillus megaterium. Proceedings of the National Academy of Sciences of the United States of America 65, 592-599.

CowAN, S. T. \& STEEL, K. J. (1974). Identification of Medical Bacteria, 2nd edn. Cambridge: Cambridge University Press.

Le Hegarat, J.-C. \& Anagnostopoulos, C. (1977). Detection and characterisation of naturally occurring plasmids in Bacillus subtilis. Molecular and General Genetics 157, 167-174.
LovetT, P. S. \& Bramucci, M. G. (1975). Plasmid deoxyribonucleic acid in Bacillus pumilus and Bacillus subtilis. Journal of Bacteriology 124, 484 490.

Murray, K. \& Murray, N. E. (1975). Phage lambda receptor chromosome for DNA fragments with HindIII and EcoRI. Journal of Molecular Biology 98, 551-564.

Novick, R. P., MURPHY, E., GrycZaN, T. J., BARON, E. \& Edelman, I. (1979). Penicillinase plasmids of Staphylococcus aureus: restriction-deletion maps. Plasmid 2, 109-129.

Sharp, R. J., Bingham, A. H. A., Comer, M. J. \& AtKinson, A. (1979). Partial characterization of a bacteriocin (thermocin) from Bacillus stearothermophilus RS93. Journal of General Microbiology 111, 449-451.

STACEY, K. A. (1968). Synthesis and properties of DNA: transformation. In Experiments in Microbial Genetics, pp. 46-51. Edited by R. C. Clowes \& W. Hayes. Oxford: Blackwell Scientific Publications.

TAnaka, T., Kuroda, M. \& SaKaguchi, K. (1977). Isolation and characterisation of four plasmids from Bacillus subtilis. Journal of Bacteriology 129, 1487-1494. 